\title{
PACIFIC CLASSICS
}

1. The Return of Lono: A Novel of Captain Cook's Last Voyage O.A.Bushnell

2. My Samoan Chief Fay G.Calkins

3. In the South Seas Robert Louis Stevenson

4. Molokai O.A.Bushnell

5. Mark Twain's Letters from Hawaii edited by A. Grove Day

6. Island Nights' Entertainments Robert Louis Stevenson 


\section{ISIAAND NIGHTS'}

\section{ENTERTAINMENTS}




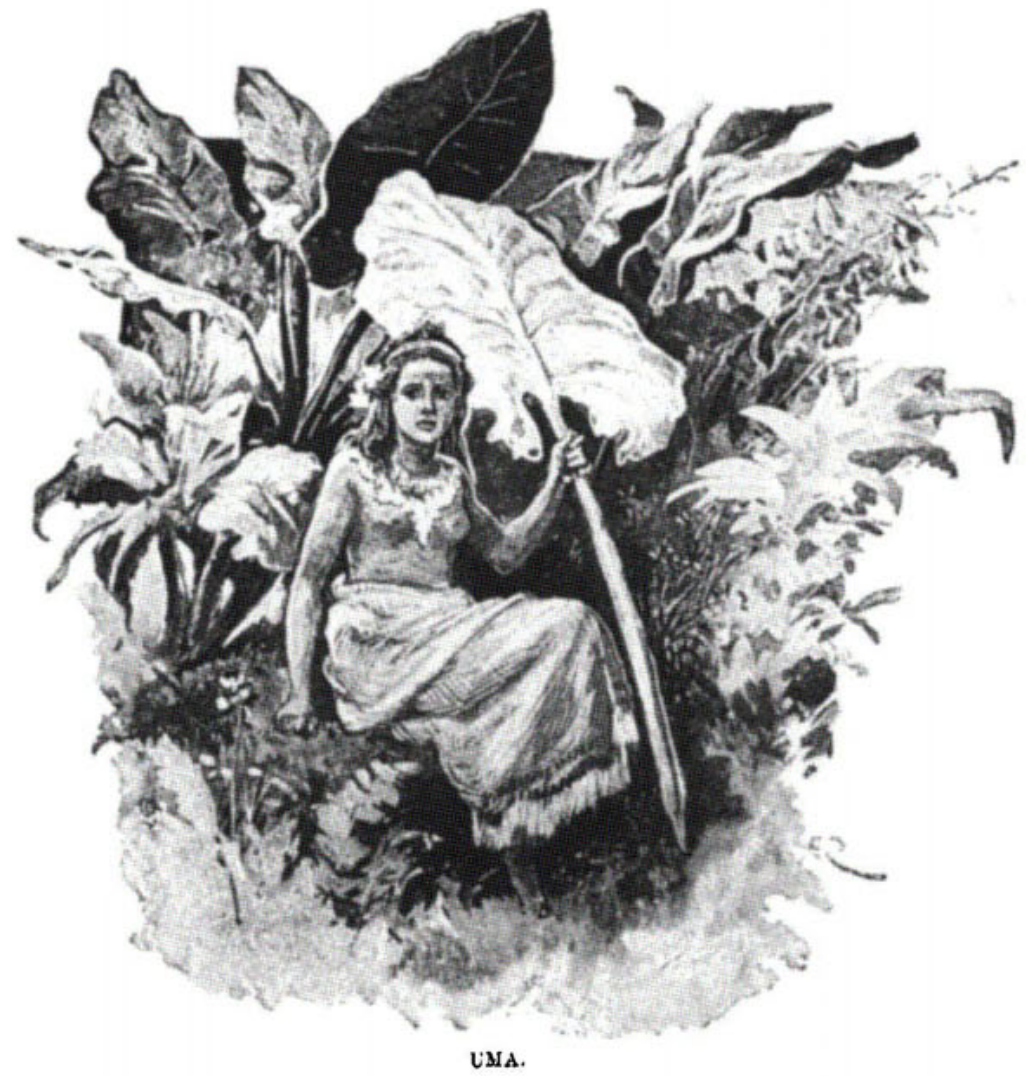




\section{ISLAND NIGHTS' ENTERTAINMENTS CONSISTING OF}

THE BEACH OF FALESÁ THE BOTTLE IMP THE ISLE OF VOICES

BY

ROBERT LOUIS STEVENSON

WITH ILLUSTRATIONS BY

GORDON BROWNE AND W. HATHERELL

FACSIMILE REPRODUCTION

INTRODUCTION BY MARJORIE SINCLAIR

THE UNIVERSITY PRESS OF HAWAII HonoluLU 
Pacific Classies Edition 1975

Originally published in 1893 by Cassell and Company

This edition is a facsimile reproduction of the Pocket Edition printed 1904, 1905, 1907 by

Cassell and Company

Copyright (c) 1975 by The University Press of Hawaii

All rights reserved

Manufactured in the United States of America

\section{Library of Congress Cataloging in Publication Data}

Stevenson, Robert Louis, 1850-1894.

Island nights' entertainments.

(Pacific classies, 6)

Reprint of the pocket ed. originally published in 1904 by Cassell, London, New York.

CONTENTS: The beach of Falesá.-The bottle imp. -The isle of voices.

I. Title. II. Series.

PZ3.S848Is25 [PR5484] $823^{\prime} .8$ 74-31328

ISBN 0-8248-0286-1 